\title{
Thomas Willis, the Restoration and the First Works of Neurology
}

\author{
LOUIS CARON* \\ Independent Scholar, 4675 Via Huerto, Santa Barbara, CA 93110, USA
}

\begin{abstract}
This article provides a new consideration of how Thomas Willis (1621-75) came to write the first works of 'neurology', which was in its time a novel use of cerebral and neural anatomy to defend philosophical claims about the mind. Willis's neurology was shaped by the immediate political and religious contexts of the English Civil War and Restoration. Accordingly, the majority of this paper is devoted to uncovering the political necessities Willis faced during the Restoration of the English monarchy in 1660, with particular focus on the significance of Willis's dedication of his neurology and natural philosophy to the Archbishop of Canterbury, Gilbert Sheldon. Because the Restoration of Charles II brought only a semblance of order and peace, Willis and his allies understood the need for a coherent defense of the authority of the English church and its liturgy. Of particular importance to Sheldon and Willis (and to others in Sheldon's circle) were the specific ceremonies described in the Book of Common Prayer, a manual that directed the congregation to assume various postures during public worship. This article demonstrates that Willis's neurology should be read as an intervention in these debates, that his neurology would have been read at the time as an attempt to ground orthodox worship in the structure of the brain and nerves. The political necessities that helped to shape Willis's project also help us to better understand Willis's innovative insistence that philosophical statements about the mind should be formulated only after a comprehensive anatomical investigation of the brain and nerves.
\end{abstract}

Keywords: Thomas Willis, Neurology, Anatomy, Restoration, Neuroscience, Cerebral Anatomy

* Email address for correspondence: Louis.R.Caron@gmail.com

I would like to recognise the valuable support I received from the Wellcome Trust, which awarded me a grant that allowed me to travel to the UK in the winter of 2012. I am grateful for the invitation to present this work to the Political Thought and Intellectual History seminar at Cambridge University in May 2013. It is a pleasure to thank Scott Mandelbrote, David Sacks, John Robertson, and Harold Cook, who read (with great patience) earlier versions of this work when it was incorporated into my doctoral dissertation. Special thanks are due to Kathryn Tabb, who read and commented on a version of this article and encouraged me to clarify my argument in various ways, and especially to Richard Serjeantson, who read multiple versions of this piece with great care. I am also grateful for the helpful guidance and comments of the two anonymous referees who read and commented on this article, and to the editors of this journal. 
Thomas Willis (1621-75) was regarded by Anthony Wood, the Oxford antiquarian, as the most 'famous physician of his time'. ${ }^{1}$ His claim to fame owed much to his medical practice, which was prolific, profitable, and (by the end of his life) highly fashionable. In the 1640s, Willis was treating patients in the country towns surrounding Oxford, but from 1667, when he moved from Oxford to London, Willis's practice was so lucrative that he left thousands of pounds and two country estates to his heirs. ${ }^{2}$ Willis's place in more modern medical histories has been secured by his invention of the term 'neurology', and his attempt to use anatomy as a means of substantiating philosophical claims about the mind. This paper considers Willis's neurology in a new context, that of a broader political and religious debate over the identity and authority of the Church of England from the 1640s, when Willis was an undergraduate at Oxford, to the publication of Willis's ultimate neurological work three years before his death in 1675. In particular, I will show that Willis had both political and intellectual reasons for writing the first works of neurology. He hoped that by pointing to new facts about the human body, he could demonstrate the beneficial effects of the religious rituals observed in the Church of England in order to answer critics of that institution. But Willis was also aware of the deficiencies in prior anatomical literature concerning the brain. Indeed, before Willis, no anatomist felt that it was appropriate to provide such a comprehensive or detailed account of the brain and nerves in order to facilitate speculations about the mind. The first works of neurology were therefore shaped both by political and religious necessity and by the opportunity to fill a gap in existing anatomical literature.

Few historians have attended to the political and religious dimension to Willis's writing. This general oversight is due to the need to see Willis as the founding figure of 'neurology', and as a major contributor to modern neuroscience. However, Willis's contribution is often discussed as a small part of a far broader development of neuroscience, which is assumed to be the sum of a trans-historical medical analysis of the brain and nerves. ${ }^{3}$ In this telling, what we know about the brain today is the culmination of human experiences with mental illness and, from the Renaissance onwards, with cerebral anatomy and the experimental physiology that came into prominence in the eighteenth century. Though he is often hailed as a major contributor to modern neuroscience, historians have difficulty explaining the modernity of his project in light of Willis's own peculiar intellectual priorities. He wrote about the brain and nerves at a time when science was really natural philosophy, when the authority of Aristotle and the standards for logic and rhetoric established in antiquity still dominated the universities, and when the end of a university education itself was

\footnotetext{
${ }^{1}$ Anthony Wood, Athenae Oxonienses: An Exact History of All the Writers and Bishops Who Have Had Their Education in the Most Ancient and Famous University of Oxford (London, 1692), ii. 402.

2 Robert L. Martensen, 'Willis, Thomas (1621-75)', Oxford Dictionary of National Biography (Oxford: Oxford University Press, Online Edition, 2007) Cited below as ODNB.

${ }^{3}$ Fielding H. Garrison, History of Neurology, Lawrence C. McHenry Jr (ed.) (Springfield: Thomas, 1969), 55-60; Israel S. Wechsler, A Textbook of Clinical Neurology with an Introduction to the History of Neurology (Philadelphia: Saunders, 1958), 709-10; Stanley Finger, Origins of Neuroscience: A History of Exploration into Brain Function (New York: Oxford University Press, 1994), 209; Graham Richards, Mental Machinery: The Origins and Consequence of Psychological Ideas. Part 1: 1600-1850 (London: Athlone Press, 1992), 74-5; Walther Riese, A History of Neurology (New York: MD Publications, 1959), esp. 7 and 63-4; Sidney Ochs, A History of Nerve Functions: From Animal Spirits to Molecular Mechanisms (Cambridge: Cambridge University Press, 2004) 75-83; Hansruedi Isler, Thomas Willis, 1621-75: Doctor and Scientist (New York: Hafner Pub. Co., 1968); James P B O'Connor, 'Thomas Willis and the Background to Cerebri Anatome', Journal of the Royal Society of Medicine, 96, 3 (2003), 139-43; A. N. Williams, 'Thomas Willis's Practice of Paediatric Neurology and Neurodisability', Journal of the History of Neurosciences, 12, 4 (2003) 350-67, esp. cf. 351; F. Clifford Rose, The History of British Neurology (London: Imperial College Press, 2012), 17-40.
} 
ordination. Whatever he may have contributed to our own understanding of the brain and nerves, Willis's works were riddled with religious sentiment and replete with philosophical preconceptions, features of his neurology that many commentators have noted, many more have dismissed apologetically, but few have seriously attempted to explain. ${ }^{4}$

Whereas such a present-oriented view of the past necessarily downplays features of the evidence that seem to have little to do with modern neuroscience, this paper focuses on the ways in which Willis's immediate religious and political circumstances shaped and even inspired his seminal neurological works. As I point out in the section immediately below, Willis wrote all of his neurological works between 1660 and 1672. The dates are important because they correspond precisely to the rise of a new political order in England. Following the civil war in England, Scotland and Ireland and the execution of King Charles I in 1649, Oliver Cromwell governed England until his death in 1658. Charles II lived in exile in France until 1660, when he returned with pomp and ceremony in the hopes that he could forge a lasting peace. Whatever else it achieved, the Restoration left unresolved the fundamental issues that had originally plunged the three kingdoms into civil war. Particularly divisive were the enduring matters of clerical authority and, more generally, of the shape of the Church of England and its liturgy. I will show here that Willis was closely associated with a group of churchmen who believed that an unwavering adherence to the liturgy described in the Book of Common Prayer was the necessary condition of a lasting peace and an obedient polity. Willis's circle of friends and theologians viewed non-conformists (those who refused to adhere strictly to Prayer Book worship) with suspicion and even hostility. Willis's clerical allies had found themselves on the losing side of the Civil War, only to be rewarded for their loyalty to Crown and church from 1660 with political advancement. It is accordingly significant that Willis only began investigating neurological matters from that year. In the first part of this article, I outline the chronological development of Willis's interests, and proceed in the second part of this article to expand upon the significance of his ties to a close-knit group of churchmen.

Willis's neurological publications were not merely the product of immediate political and religious necessity; they were also the works of an ingenious and learned physician who understood (and even exploited) the state of the art in order to upstage both prior anatomists and philosophers. In the final section of this paper, I demonstrate that anatomists who wrote about the brain before Willis universally declined to offer speculations about the mind. I proceed from there to show how Willis openly defied this convention in writing about the brain and nerves in a way that, while not wholly new, clearly demonstrated his command of the existing anatomical literature. If Willis's role as the founder of neurology is to be understood in strictly historical terms, he must be seen to be doing more than just anatomy: his contribution to medicine should be seen to reflect his own particular political and religious sympathies. Willis wrote about the brain and nerves at a particular moment in time for reasons that were not purely those of a curious scientist.

\footnotetext{
${ }^{4}$ Cf. Isler, Thomas Willis, 106, 191-2; Hansruedi Isler, 'The development of neurology and the neurological sciences in the 17th century', in Stanley Finger, François Boller, and Kenneth L. Tyler (eds), History of Neurology (Edinburgh: Elsevier, 2010), 91-106; John D. Spillane, The Doctrine of the Nerves: Chapters in the History of Neurology (Oxford: Oxford University Press, 1981), 107; J. Trevor Hughes, Thomas Willis (1621-75): His Life and Work (London: Royal Society of Medicine Services, 1991), 20, 30-1; See the introductions to Kenneth Dewhurst, Thomas Willis's Oxford Lectures (Oxford: Sandford Publications, 1980); Kenneth Dewhurst, Willis's Oxford Casebook 1650-52 (Oxford: Sandford Publications, 1981).
} 
Thomas Willis was born to a family of middling gentry in Great Bedwyn, Wiltshire, on 21 January $1621 . .^{5}$ Universities at this time were still primarily seminaries and, after receiving his BA on 12 June 1639 and MA on 18 June 1642, Willis may have initially pursued studies towards ordination. Normally, after taking the MA, students would be expected to pursue either a Doctorate in Divinity or a higher degree in the faculty of either law or medicine. However, 1642 also marked the outbreak of civil war in England, and Willis found himself at turns away from the university at his family home or serving in the garrison for King Charles. Royalists occupied Oxford from 1643, and for the next three years - until the surrender of the city to parliamentary forces in 1646 - normal academic life at the university ground to a halt. There is no evidence that Willis was ever forced to undergo the rigorous scholarly requirements that had been imposed on prior graduates. Instead, like many contemporary students of medicine who were loyal to the king, Willis was actually created a Bachelor of Medicine by royal decree in $1646 .{ }^{6}$

What little is known about Willis's activities from 1646 to 1660 comes from scant manuscript material, much of which has been published. ${ }^{7}$ Since this discussion is concerned primarily with Willis's subsequent works on neurology, it will suffice here to give a brief summary of this evidence, if only to demonstrate that Willis's intellectual focus shifted after the Restoration of 1660. Before that year, much of Willis's time was spent practising medicine in and around Oxford. In the years following the surrender of Oxford to parliamentary forces in 1646, Willis began his chemical and anatomical learning alongside William Petty. Petty served first as the Tomlins reader in anatomy, and then as deputy to the Regius professor in physic. ${ }^{8}$ Both Willis and Petty received widespread notoriety for their involvement in the resurrection of a woman named Anne Greene. Greene had been found guilty of infanticide and hanged for the crime, and her seemingly lifeless body was delivered to Willis's residence for anatomisation. Before the dissection could be performed, however, Greene showed signs of life and, in the presence of the other prominent men, Willis and Petty resuscitated Greene. ${ }^{9}$ Willis was thus an integral member of a group of prominent experimentalists, many of whom would go on to

\footnotetext{
${ }^{5}$ Willis's biographers disagree over his father's educational history, for which see John Fell, Postscript, in Thomas Willis, Pharmaceutice Rationalis: Or, An Exercitation of the Operations of Medicines in Humane Bodies, pt II, sigs. A3r-A4r, quoted from sig. A3v, which was reprinted in Thomas Willis, Dr Willis's Practice of Physick, Being all the Works of that Renowned and Famous Physician, Samuel Pordage (trans.), (London, 1684). All citations of Willis's works are drawn from Pordage's translation and cited by the title and the page number of each work as they appear in the 1684 edition. Compare Fell's account at the end of the Pharmaceuticae Rationalis with Wood, Athenae Oxonienses, ii. 403.

${ }^{6}$ On the degree requirements see Robert G. Frank Jr., 'Medicine', in Nicholas Tyacke (ed.), The History of the University of Oxford; Volume IV, Seventeenth-Century Oxford (Oxford: Clarendon Press, 1997), 508: 516-20; Details regarding Willis's degrees are also reported in Robert Martenson, 'Willis, Thomas (1627-75)', ODNB. On the granting of degrees see Ian Roy and Dietrich Reinhart, 'Oxford and the civil wars', in Seventeenth-Century Oxford, 708; Frank, 'Medicine', in ibid., 514.

${ }^{7}$ Willis's sole surviving casebook from 1650-52, which is in the Wellcome Trust Library in London, has been translated and edited by Dewhurst as Willis's Oxford Casebook, op. cit. (note 4); see also Kenneth Dewhurst, 'Some Letters of Dr Thomas Willis 1621-75', Medical History, 16 (1972), 63-76.

${ }^{8}$ Frank, op. cit. (note 6), 543; Robert G. Frank, Harvey and the Oxford Physiologists: A Study of Scientific Ideas (Berkeley: University of California Press, 1980), 101-3; Toby Barnard, 'Petty, Sir William (1623-87)', ODNB.

${ }^{9}$ The incident was published in an account by Richard Watkins, Newes From the Dead. Or A True and Exact Narration of the Miraculous Deliverance of Anne Greene (Oxford, 1651) quoted from 8. Scott Mandelbrote, 'William Petty and Anne Greene: Medical and Political Reform in Commonwealth Oxford' in The Practice of Reform in Health, Medicine, and Science, 1500-2000; Margaret Pelling and Scott Mandelbrote (eds), Essays for Charles Webster (Aldershot: Ashgate, 2005), esp. 125-6.
} 
be active members of the Royal Society. Petty was joined in Oxford in 1655 or 1656 by Robert Boyle (1627-91), who shortly thereafter began his experiments with an air pump. ${ }^{10}$ Willis's contribution to the efforts of these men earned him a reputation as an ingenious and precise experimentalist. From 1648, John Lydall wrote to John Aubrey to report on the experiments of Willis, 'our Chymist'. ${ }^{11}$

Though Willis might have had an interest in anatomy, there is no evidence he had even pondered the possibility of something called 'neurology' before 1660. Instead, Willis was primarily interested in chemistry and its application to medicine. Thanks to a letter sent to the intelligencer Samuel Hartlib by John Aubrey, we know Willis had been working on his views concerning the fermentation of natural bodies since at least 1656. ${ }^{12}$ The work was eventually published as Diatribae Duae Medico-Philosophicae [Two Medical-Philosophical Treatises] in 1659. Though commonly referred to as the Two Tracts, the published version of this work contains three distinct treatises: one on fermentation (the De Fermentatione), one on fevers (the De Febribus) and a shorter essay on urines (the Dissertatio Epistolica De Urinis). In these works, Willis described diseases (especially fevers) in terms of a material change which occurred when any of the five principal parts of the material world (spirit, sulphur, salt, water and earth) were mixed or forcibly recombined. Willis's Diatribae Duae are therefore significant because they advertise Willis as a physician familiar with the new learning, especially the influential theory of the circulation of the blood pioneered by William Harvey (1568-1657), and as a practitioner who was engaged in legitimate and learned chemical experimentation. ${ }^{13}$

Following the Restoration of Charles II, Willis was elected Sedleian Professor of Natural Philosophy at Oxford in 1660, having been made a Doctor of Medicine that same year. It was from this point in time that Willis turned to the anatomy of the brain and nerves, and in four years the Cerebri Anatome ([The Anatomy of the Brain] 1664) appeared. It was in the Cerebri Anatome that Willis coined the term 'neurologia', or what he elsewhere referred to as the 'doctrine of the nerves'. Willis deployed this neologism to indicate his intention to perform a comprehensive and detailed analysis of the brain and nerves in order to substantiate a new pathology and a new physiology. The titles of his subsequent works suggest the progress of his research from anatomy to pathology, and eventually to physiology: his next neurological work was the Pathologiae Cerebri et Nervosi Generis Specimen ([An Essay on the Pathology of the Brain and Nerves] 1667); five years later there appeared the De Anima Brutorum, Quae Hominis Vitalis ac Sensitiva Est, Exercitationes Duae ([Two Discourses Concerning the Soul of Brutes, which is that of the Vital and Sensitive in Man] 1672). Taken together, these works present the first systematic attempt to integrate anatomical observations into a broader philosophical argument about human nature.

He dedicated each of his neurological works to Gilbert Sheldon (1598-1677), who was the Archbishop of Canterbury from 1663 and whose importance to Willis's medical publications deserves emphasis here, and will be further clarified below. Indeed, in the third edition of the Diatribae Duae (printed in 1662), Willis acknowledged that it was

\footnotetext{
${ }^{10}$ Michael Hunter, 'Boyle, Robert 1627-91', ODNB.

11 Bodleian Library, MS Aubrey 12, fol. 294r.

12 Aubrey reported that Willis 'hath written a treatise De Fermentatione'. The Hartlib Papers, 2nd edn (Sheffield: University of Sheffield, 2002) 'Ephemerides' 1656, 29/5/102A. Frank, Harvey and the Oxford Physiologists, op. cit. (note 8), 165 .

${ }^{13}$ Michael Hawkins, 'Piss Profits: Thomas Willis, His Diatribae Duae and the Formation of His Professional Identity' History of Science, 44 (2011), 1-24.
} 
through Sheldon's influence 'that I obtained the Votes in this Famous University for the Place of Sidly Professor'. ${ }^{14}$ Willis's gratitude to his patron was not merely a formality. He wrote in the De Anima Brutorum that none of his neurological publications would have 'ever seen the Light. . . unless I had been made at first your Sidlie Professor at Oxford' ${ }^{15}$ However, Willis's debt to Sheldon extended beyond matters of professional advancement. The physician had close personal ties to the Archbishop, and he intended his neurology to serve the ideological and political ends of Sheldon's church.

In this regard, Willis's turn to the anatomy of the brain and nerves in 1660 was not merely the choice of a curious natural philosopher; his shift towards neurology was religiously motivated. However, some caution is needed when dealing with motives and motivations. As intellectual historians and historians of political thought have often reminded us, it is dangerous if not simply impossible to attempt to divine the private motivations of an author from words they wrote long ago. We are fortunate in this case, because Willis made his motivations quite public by dedicating nearly every work on anatomy, physiology and psychology to Sheldon. ${ }^{16}$ Indeed, he intended that his natural philosophical publications 'be not referred to my Ingenuity, or (which I might perhaps more truly deserve) my Industry, but to the Influences of my Patron' ${ }^{17}$

When Willis wrote his dedicatory epistles, Sheldon was one of the most powerful churchman in England from the Restoration. But Willis's dedicatory epistles to Sheldon were more than mere performance; they also reflected a deep personal affinity between the two men. In the decades preceding the publication of the first works of neurology, Willis was involved with a circle of clerics who had been favoured during Charles I's reign, and who would again rise to prominence for their continued loyalty following the Restoration. This group included Sheldon, Richard Allestree (1619-81), Brian Duppa (1588-1662), John Dolben (1625-86), Willis's brother-in-law, John Fell (1625-86) and (from 1648) the theologian and controversialist, Henry Hammond (1605-60). By the time Willis had published his final work on the brain and nerves, the De Anima Brutorum (1672), Hammond had been dead for more than a decade. But it was Hammond's views on human agency, sin and morality that helped to shape Willis's neurological theories. Hammond was the most influential and prolific of the group that included Sheldon, Allestree and both Samuel and John Fell. These men were notorious for their insistence that only bishops had the power to ordain and to lead the church, and that liturgical uniformity and ceremonialism were essential to the true religion.

Willis's circle of Oxford theologians also favoured Archbishop William Laud (15731645) and his governance of the early Stuart church. For Laud, religion served both spiritual and political ends. Maintaining strict obedience and discipline in each parish ensured a docile and loyal polity, and contributed to an effective and benevolent state. Laud's opponents within the church vilified him for his seemingly Roman Catholic

\footnotetext{
${ }^{14}$ Willis, Two Treatises, A4v.

15 Willis, Soul of Brutes, A2r.

16 There are three titles that do not follow this general rule. They are Thomas Willis, Affectionum Quae Dicuntur Hystericae et Hypochondriacae Pathologia Spasmodica Vindicata, Contra Responsionem Epistolarem Nathanae Highmori. M D. (London, 1670); Thomas Willis, Pharmaceutice rationalis, sive, Diatriba de medicamentorum operationibus in humano corpore, published in two parts (Oxford, 1674-5); Thomas Willis, A plain and Easie Method for Preserving (by God's blessing) Those that are Well from the Infection of the Plague, or any Contagious Distemper in City, Camp, Fleet, \& c. and for Curing Such as are Infected with it: Written in the Year 1666 (London, 1691).

17 Op. cit. (note 14).
} 
aspirations, an attitude that failed to recognise the Archbishop's demonstrable aversion to the Catholics in Charles I's court. There is no question that Laud's innovative efforts to bring the English people into line with his vision of religion generated a widespread and very real animosity towards the established church. ${ }^{18}$ Liturgical uniformity had long been a pressing concern for the clerical leaders of the Church of England, and Laud approached the issue with unparalleled aggression and zeal. He silenced critics of his church through threats of legal action, he stifled dissenting voices within the ministry and he actively promoted like-minded ministers to the universities of Cambridge and Oxford. ${ }^{19}$ His policies generated so much resentment that he was eventually indicted, imprisoned and executed. The church Laud helped to create was also uprooted by the Long Parliament's abolition of episcopacy and their implementation of new liturgical standards that were advertised as more perfectly representing the primitive church. ${ }^{20}$ In a nation that was supposedly reformed, Laud's insistence on ceremonial uniformity, which entailed kneeling at various times during a service and the wearing of the surplice, were frequently and correctly perceived to have no precedent in the earliest Christian communities. The Church of England was certainly transformed by the abolition of bishops, but the same reverence for local customs that had thwarted previous attempts to impose liturgical conformity endured, much to the frustration of reformers in the $1640 \mathrm{~s}$ and $1650 \mathrm{~s}^{21}$

Loyalty to church and Crown were essential virtues for Willis's circle of theologians. Until 1647, Sheldon and Hammond served Charles I as spiritual advisors. ${ }^{22}$ Samuel Fell (1584-1649), John Fell's father, had helped to organise the loan of $£ 14283$ made by the colleges and University of Oxford to the Royalist cause at the outset of the war. ${ }^{23}$ Following the surrender of Oxford, parliamentary visitors arrived intent on expelling those academics and clerics who sympathised with the Crown or the Laudian church and replacing them with men sympathetic to Parliament and the religious and institutional reform of the colleges and university. In 1646, Fell was at the forefront of a delegation of college officers that formulated a coherent assertion of the antiquity and legality of episcopacy, in order to establish the impossibility of submission to the oaths newly required by Parliament. Sheldon's own resistance to parliamentary visitation resulted in his being stripped of the wardenship of All Souls College, which he had held since 1635. He was also forcibly removed from his rooms and incarcerated in $1648 .{ }^{24}$ Samuel Fell was also imprisoned, and parliamentary officers ejected his family (including Mary Fell, Willis's future wife) from their rooms at Christ Church. ${ }^{25}$

During the 1640s and 1650s, the men in Sheldon's orbit - despite being marginalised by their political opponents - worked tirelessly to preserve the essence of the English church as it had existed before the civil war. As John Fell recalled in his obituary of Willis, 'the Church being trampled on, and Divinity together with Divines Suppressed', the physician

\footnotetext{
18 Anthony Milton, 'Laud, William (1573-1645)', ODNB.

19 John Morrill, 'The religious context of the English Civil War', in John Morrill (ed.), The Nature of the English Revolution (Essex: Longman, 1993), 51.

${ }^{20}$ David Como, 'Predestination and Political Conflict in Laud's London', Historical Journal, 46 (2003), $263-94$.

${ }^{21}$ John Spurr, The Restoration Church of England, 1646-89 (New Haven: Yale University Press, 1991), 5-7; 18-20: John Morrill, 'Attack on the Church of England', English Revolution, 172-3; Robert Bosher, The Making of the Restoration Settlement: The Influence of the Laudians, 1649-62 (Westminster: Dacre Press, 1957), 16-17.

22 Hammond and Sheldon were traveling with Charles I as his chaplains until December of 1647. Hugh de Quehen, 'Hammond, Henry (1605-60)', ODNB; John Spurr, 'Sheldon, Gilbert (1598-1677)', ODNB.

${ }^{23}$ Roy and Reinhart, 'The Civil Wars', History of the University of Oxford, 695.

${ }^{24}$ Spurr, 'Sheldon, Gilbert', ODNB.

${ }^{25}$ Roy and Rienhart, op. cit. (note 23), 724-6.
} 
'entertained Religion then a Fugitive' in his own house, a recollection corroborated by Wood. ${ }^{26}$ When Hammond died in 1660, his autopsy was performed by Willis and later published in the De Anima Brutorum. Fell integrated Willis's clinical observations into his biography of Hammond. ${ }^{27}$ Hammond had praised Willis's abilities and reputation as a healer to Sheldon ${ }^{28}$ and had named Willis in his will as both his friend and physician. ${ }^{29}$ Willis was also Sheldon's physician. In the De Anima Brutorum, Willis recalled that Sheldon had suffered from a sudden (but curable) apoplexy six years earlier. The De Anima Brutorum was published in 1672, and it seems likely that Sheldon's condition was a primary factor in Willis's move to London in $1666 .{ }^{30}$

These close personal ties to such a powerful group of churchmen have been generally underplayed or ignored, especially in histories of neuroscience written for a scientific audience, but equally in the works of professional historians of medicine. For example, both Robert Frank and Kenneth Dewhurst, who have made major contributions to our understanding of Willis's natural philosophy, have overlooked or underplayed the deep connections to the churchmen I listed above. ${ }^{31}$ Even in his important work on Willis's development as a physician in the 1650s and his consideration of the Restoration debates that shaped Willis's neurology, Michael Hawkins makes only passing reference to the religious content of Willis's writing and does not expound upon the significance of Willis's personal ties to these churchmen. ${ }^{32}$

Only two historians prove exceptions to this rule. The late Robert Martensen argued that Willis's natural philosophy exhibits the influence of 'High Church politics', and that "Willisian "facts" rang true to a collective imagination of nature and society preoccupied with hierarchical order'. For Martensen, that order entailed 'an episcopally ordered church as the reasonable "head" of the nation'. ${ }^{33}$ His analysis turns on the claim that Willis's vision of the body reflected some version of a seventeenth-century commonplace, the metaphorical 'body politic'. In making this claim, Martensen was on somewhat dubious historical ground. None of Willis's allies questioned the fact that the king was the head of both church and state. More problematically, the equivalence between anatomy and hierarchy is really Martensen's, not Willis's: nowhere in Willis's writing is there any

\footnotetext{
${ }^{26}$ See the unpaginated postscript to the second part of Pharmaceutice Rationalis: Or, An Exercitation of the Operations of Medicines in Humane Bodies, op. cit. (note 5); Wood, Athenae, op. cit. (note 1) ii. 402.

${ }^{27}$ Willis, op. cit. (note 15), 224-5; John Fell, The Life of the Most Learned, Reverend and Pious Dr Hammond (London, 1661), 224.

28 British Library, MS Harley 6942 fo. 66r, 87r.

${ }^{29}$ Hammond's will has been reproduced in John Packer, The Transformation of Anglicanism 1643-60 with Special Reference to Henry Hammond (Manchester: Manchester University Press, 1969), plate 1.

${ }^{30}$ Willis, op. cit. (note 15), 160.

${ }^{31}$ Cf. Robert G. Frank, 'Thomas Willis and his circle: brain and the mind in seventeenth-century medicine', in G.S. Rousseau (ed.), The Languages of Psyche: Mind and Body in Enlightenment Thought: Clark Library Lectures 1985-6 (Berkeley: University of California Press, 1990), 107-46: 113-4: 123; Robert G. Frank, 'Willis, Thomas', in Charles Gillispie, Frederic L. Holmes, Noretta Koertge (eds), Complete Dictionary of Scientific Biography (Detroit: Charles Scribner's Sons, 2008), xiv. 404-9; cf. as well the works cited above in note 4.

${ }^{32}$ Cf. Michael Hawkins, "A Great and Difficult Thing”: understanding and explaining the human machine in restoration England', in Iwan Rhys Morus (ed.), Bodies/machines (New York: Bloomsbury Academic, 2002), $15-38$.

${ }^{33}$ Robert Martensen, "'Habit of Reason”: Anatomy and Anglicanism in Restoration England', Bulletin of the History of Medicine 66, 4 (1992), 511-35, quoted from 511 and 533; See also Robert Martensen, The Brain Takes Shape; an Early History (Oxford: Oxford University Press, 2004), 88; Robert Martensen, 'When the brain came out of the skull: Thomas Willis (1621-75), anatomical technique and the formation of the "cerebral body" in seventeenth century England', in F. Clifford Rose (ed.), A Short History of Neurology: The British contribution 1660-1910 (Oxford: Butterworth-Heinemann, 1999), 19-35.
} 
extended comparison between the human body and the body politic. Rina Knoeff has provided the only other existing analysis of Willis's religious commitments. Knoeff focused in particular on how Willis's religious ties form the background to his description of the intercostal nerve. On Knoeff's account, Willis's neurology represents an 'Anglican optimism' about the moral capacities of the human being. ${ }^{34}$

However, there is reason to cast the religious background for Willis's neurology in a far more authoritarian (and far less benevolent) light. Willis not only hoped his Cerebri Anatome would prove the most complete and influential account of the brain and nerves that had ever been published, he intended that what he wrote in each of his neurological works would provide a natural basis from which to defend the authority of the church as it existed from 1662. Willis set out to show that the human body had been made by God to benefit from the ceremonies described in the Book of Common Prayer and to undermine accounts of the soul and body that called into question the need for uniformity in worship and obedience to Sheldon's authority as archbishop. It is necessary, therefore, to treat Willis's dedications to Sheldon as an invitation to consider his place in the context of ongoing religious debates over the identity and authority of the church.

\section{II}

In the eyes of Willis and his clerical allies, the true religion required not only the absolute authority of bishops in spiritual matters, but also a strict observance of the Prayer Book in all forms of worship. Obedience in matters of religion would ensure political obedience, and accordingly these men prayed the king would entrust them with the spiritual health of England. Of course the upheavals of the 1640s and 1650s only confirmed to Sheldon and his circle that religious heterodoxy was the harbinger of total disorder. These men could only watch as their church was totally uprooted; the bishops were abolished, and Laud was impeached for high treason by the Commons in 1640, imprisoned in the Tower in 1641 and finally executed in 1645. That same year the Prayer Book was replaced by the Directory of Public Worship, though throughout England the Prayer Book would continue to be used in private (even despite the fact that it was again banned in 1655). Though their church was dismantled, Willis worked alongside Sheldon, Hammond and other loyalists to preserve the spirit of their church through covert ordinations and private services. Even as altars were stripped and public worship in accordance with the Prayer Book was proscribed, Hammond and Allestree published a range of moral and apologetic works that counselled churchmen and loyalists on how to conform to the new political order without betraying the true religion. ${ }^{35}$

Following the death of Cromwell in 1658, it became increasingly clear that Charles II would be returned to power. With the Restoration of the monarchy would come the resurrection of the Church of England, though until 1662 the shape and authority of the Restoration church was still hotly contested. The political peace in the early years of

\footnotetext{
${ }^{34}$ Rina Knoeff, 'The Reins of the Soul: The Centrality of the Intercostal Nerves to the Neurology of Thomas Willis and to Samuel Parker's Theology', Journal of the History of Medicine and Allied Sciences, 59, 3 (2004), 413-40.

${ }^{35}$ Kenneth Fincham and Stephen Taylor, 'Episcopalian conformity and non-conformity, 1640-60' in Jason McElligott and David Smith (eds), Royalists and Royalism during the Interregnum (Manchester: Manchester University Press, 2010), 21-2: 24: 30-3; Spurr, Restoration Church, op. cit. (note 21), 9, 141-3; Henry Hammond, A Practical Catechism (London, 1649); Richard Allestree, The Whole Duty of Man (London, 1658), and in multiple editions thereafter.
} 
Charles II's reign was fragile, the appearance of order an illusion that barely concealed the continued factionalism in the English polity. The Restoration church was shaped by the same men who had found themselves among a persecuted minority, being forced to worship in the privacy of Willis's home. John Fell was appointed Dean of Christ Church, while Allestree was promoted first to Canon of Christ Church, and subsequently to Provost of Eton and Regius professor of theology at Oxford. ${ }^{36}$ It is not unreasonable to suspect that Willis's loyalty to Sheldon derived as much from his obligations to his patron as from his own fervent religious convictions. From 1657 Willis was married to John Fell's sister, Mary Fell. She died tragically in 1670, but when Willis married again he chose Elizabeth Calley (1634/5-1709), a widow with her own ties to episcopacy - her father was Matthew Nicholas (1594-1661), a former dean of St Paul's. ${ }^{37}$

With his rise to archbishop in 1663, Sheldon took firm control of a newly unified but equally coercive establishment. From 1660-62, and even well into the later years leading up to the Exclusion Crisis of 1680, Prayer Book loyalists (with Sheldon as their leader) continued to fear the political threat posed by non-conformists. ${ }^{38}$ It was under Sheldon's influence that Parliament passed the 1662 Act of Uniformity, which led to the ejection of 936 ministers, many of whom were moderates caught up in a backlash against the perceived threat of sectarianism. Non-conformists faced further challenges in the acts of 1664 and 1665, when justices of the peace were granted the power to enter any house suspected of hosting an unauthorised meeting. Those who chose not to accommodate themselves to the new standards of uniformity were prohibited from living within five miles of their community unless they swore they would not endeavour to alter the government. ${ }^{39}$ Legal prosecution was Sheldon's primary weapon against nonconformists; he did not care to compromise standards of uniformity in order to bring moderates into the fold (comprehension), nor could Sheldon allow even obedient nonconformists the opportunity to worship in private in accordance with the dictates of their own conscience (toleration). In Sheldon's eyes, those who refused to obey his authority, and to submit to the law, were beyond the pale of reason. When he wrote to the Duke of Ormonde in 1663 , Sheldon explained that the only means of curbing non-conformity was 'a resolute execution of the law' because those 'who will not be governed as men by reason and persuasion, should be governed as beasts by power and force, all other courses will be ineffectuall, ever have been soe, ever will be' ${ }^{40}$ However, persecution only hardened the resolve of non-conformists, and the exclusion of so many respected, moderate clerics from their livings created the conditions for an endemic resistance to Sheldon's authority. Throughout the later 1660s, Sheldon received reports detailing the spread of conventicles of non-conformists worshipping in private..$^{41}$

Sheldon's intolerance towards non-conformists helps to explain the political significance of Willis's appeal to the Archbishop in his neurological works. While we cannot speculate about how Willis's readers perceived such an appeal, it is at least certain that Sheldon

\footnotetext{
36 The claims about Sheldon's instrumental role in the formulation of the acts of uniformity are laid out by Spurr, Restoration Church, 47-8. Andrew M. Coleby, 'Dolben, John (1625-86)' ODNB; Spurr, 'Allestree, Richard (1621/2-81)', ODNB. Vivienne Larminie, 'Fell, John (1625-86)', ODNB.

${ }^{37}$ Martensen, 'Willis, Thomas (1621-75)', ODNB.

38 Mark Goldie, 'Danby, the Bishops and the Whigs', in Tim Harris, Paul Seaward, and Mark Goldie (eds), The Politics of Religion in Restoration England (Oxford: Basil Blackwell, 1990), 75-106, esp. 77-8.

${ }^{39}$ Spurr, Restoration Church, op. cit. (note 21), 43-7.

${ }^{40}$ Bodleian Library, MS Carte 45, f. 151r. Originally quoted in Spurr, 'Sheldon', ODNB.

${ }^{41}$ Bodleian Library, MS Add. C 308, fos. 73v, 76r-v, 79v, 80r, 140v-141r.
} 
and Willis shared an acute distrust for non-conformity, and that both felt the need to do what they could to extend the authority of the Restoration Establishment. In light of their close personal ties, it also seems likely that Sheldon had Willis promoted within Oxford because he trusted the physician would serve the ends of the Restoration church. Willis did not disappoint. He declared in the Cerebri Anatome that the truths he uncovered would be verified both by 'the demonstration of Piety and Canons of the Church' and by 'the Rule of Experience and Knowledge'. ${ }^{42}$ He intended that the De Anima Brutorum should be received as 'altogether Orthodox' and 'agreeable to a good Life, and Pious Institution'. ${ }^{43}$ Willis wrote these words at a time when England was increasingly divided between conformists and non-conformists (to say nothing of the persistence of recusants and conforming Roman Catholics). His appeals to orthodoxy were neither superficial nor platitudinous.

However, appeals to orthodoxy do raise a number of interpretive difficulties. One of the major issues lies in characterising the Stuart church as a whole, and the recent historiography has rightly moved away from simple oppositions between 'Puritans' and 'Anglicans' and towards a more nuanced view about differences over ecclesiology, theology, soteriology and liturgy. Anthony Milton's sensitive reading of the debates within the church has revealed a spectrum of beliefs about salvation, the attributes of God and the relationship between the English, Roman and other Protestant churches. ${ }^{44}$ Milton's approach has complicated Nicholas Tyacke's thesis that conflicts within the early Stuart church occurred primarily between parties devoted to the theological writings of John Calvin (1509-64) or Jacobus Arminius (1560-1609). ${ }^{45}$

Calvin emphasised the total reprobation of individuals, and their complete dependence on God's judgment. However, on Calvin's account, God had determined from the beginning who was saved and who damned; human experience merely revealed the dictates of His will. Arminius countered by emphasising the benevolence and agency of God and human beings over the course of time. It was a theology that appealed to the power individuals had to behave virtuously and to shape their own fate in the next life. In broad terms, those in the Church of England who appreciated the need for liturgical uniformity were convinced that humans were free to act and to behave in virtuous or vicious ways, while those who rejected liturgical uniformity were convinced their salvation depended upon the will of God, rather than the particular forms of worship in a particular church. But this is merely a basic, and deceptively simple, mapping of these theological positions onto Stuart church politics. The fact is that many conformists within the Church of England were Calvinists and, with reference to Willis's circle of High Churchmen, none of them should be regarded as 'Arminian', as they expressed a range of views on salvation. ${ }^{46}$

Willis's appeal to orthodoxy requires an awareness of this complicated debate over the nature, scope and authority of the Church of England, primarily because that awareness

\footnotetext{
42 Willis, Anatomy of the Brain, G2v.

43 Willis, op. cit. (note 42), A4r.

44 Anthony Milton, Catholic and Reformed: The Roman and Protestant Churches in English Protestant Thought, 1600-40 (Cambridge: Cambridge University Press, 1996 [2002]).

45 Nicholas Tyacke, Anti-Calvinists: The Rise of English Arminianism c.1590-1640 (Oxford: Oxford University Press, 1990 [1987]).

46 David Como, 'Puritans, predestination, and the construction of orthodoxy in seventeenth-century England' in Peter Lake and Michael Questier (eds), Conformity and Orthodoxy in the English Church, c. 1560-1642 (Suffolk: Woodbridge, 2000), 64-87; Peter White, Predestination, Policy and Polemic; Conflict and Consensus in the English Church from the Reformation to the Civil War (Cambridge: Cambridge University Press, 1992).
} 
helps to frame the language used by Willis's opponents in their attacks upon the legitimacy of the church both before 1645 and after 1662. He published his neurological works at a time when non-conformists were being actively prosecuted because they refused to accept that the particular form of worship being imposed upon them conveyed any spiritual benefit: at best, the ceremonies described in the Book of Common Prayer were matters indifferent to salvation, because salvation depended upon divine judgment; at worst, the rituals were so close to Roman Catholicism they actually scandalised those who conformed. This is only to give the barest outline of the debates that raged on for decades before and after the civil wars ${ }^{47}$ but it will be sufficient here to show that Willis's neurology was aligned perfectly with the view that the rituals described in the Prayer Book were beneficial for anatomical and physiological reasons.

Of particular significance is Willis's invocation of Henry Hammond's theology in his De Anima Brutorum. Hammond's view of human nature was shaped both by an earnest belief in the perfectibility of human nature through religion, and by the need to defend the Laudian church and the authority of the bishops in the 1640s. His theology was equal parts polemic and scholarship. But Hammond's views were not a product of an identifiably 'Arminian' doctrine. As Sarah Mortimer has shown, Hammond's own conceptions of the human will and the role of good works suggest the influence of a variety of authors, including Arminius and Hugo Grotius (1583-1645), but also the controversial theologian Faustus Socinus (1539-1604). ${ }^{48}$ Hammond turned to these sources, and relied upon his own reading of Scripture, to refute a range of competing views. In order to better understand his influence on Willis, it will be helpful to highlight how Hammond's views of human nature were shaped to refute a stereotypically Calvinistic account of conscience.

As I mentioned above, Calvin insisted on the total reprobation of the human being, and on the will of God and the work of the Holy Spirit as the sole source of moral edification. He pitted the immutable will of God against the presumed power of the human will. For Calvin, there was no medium between the soul and the body. He understood the terms 'spirit' and 'soul' to refer to the same thing. ${ }^{49}$ Calvin did so in order to reject the distinction between the 'sensitive' and the 'rational soul' found in Plato and Aristotle. ${ }^{50}$ Classical philosophers had made this distinction in order to explain how the higher faculties of the mind could overcome the impulses of the body. Yet, for Calvin, this failed to account for the total corruption of human reason. Humans were so depraved after Adam's fall that the intellect was incapable of acquiring any real moral knowledge on its own. Neither reason nor the faculties of sensation could guide one to virtue. Calvin attributed virtuous actions or events that manifested some truth entirely to the operations of God's spirit. ${ }^{51}$ The 'fleshe is not capable of so hye wisedome to conceiue God and that which is Gods', Calvin asserted, 'vnlesse it be lightened with the spirite of God'. ${ }^{52}$ That spirit afflicted the conscience with warnings of imminent judgment, driving humans to perform that which they 'owe to God, and layeth before [them] the difference of good and euell, and so accuseth vs when [they]

\footnotetext{
${ }^{47}$ See for example Jacqueline Rose, 'John Locke, "Matters Indifferent", and the Restoration of the Church of England', Historical Journal 48 (2005), 601-21.

${ }^{48}$ Sarah Mortimer, Reason and Religion in the English Revolution: The Challenge of Socinianism (Cambridge: Cambridge University Press, 2010), 82-3: 124-32.

49 Jean Calvin, The Institution of Christian religion, Wrytten in Latine by maister Ihon Caluin, and Translated into Englysh According to the Authors Last Edition (London, 1561), I.xv.2.

${ }^{50}$ Calvin, Institutes, I.xv.6.

${ }^{51}$ Calvin, op. cit. (note 49) II.ii.15-16.

${ }^{52}$ Ibid., II.ii. 19.
} 
swarue from [their] dutie'. ${ }^{53}$ A central part of Calvin's theology, then, was the absence of any psychological medium between the human soul and the divine will.

Hammond developed his own characteristic view of human nature in the course of answering critics of his church throughout the 1640s and 1650s. Broadly speaking, Hammond asserted (pace the Calvinists) that human beings did in fact have both spirits and souls. The most definitive statement of this view occurs in Hammond's A Paraphrase, and Annotations Upon All the Books of the New Testament (1653); specifically in the divine's explanation of 1 Thess: 5:23 in which Paul hoped 'the very God of peace' would 'sanctifie' the letter's recipients, and that 'God your whole spirit and soul and body be preserved blamelesse unto the coming of the Lord Jesus Christ'. Hammond's paraphrase

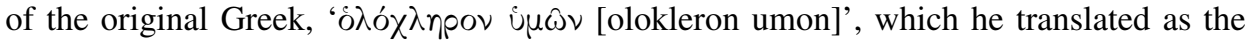
'whole of you', would later provide the scriptural basis for Willis's physiology. However, it was a foundation that relied more on Hammond's paraphrase than on the plain words of scripture. For Hammond, Paul used the Greek phrase quoted above to indicate 'the all, or whole of you, the intire or complete man is here divided into three parts, spirit, soul, and body'. Hammond went on to elaborate upon this tripartite division of spirit, soul and body, claiming that what Paul wrote as 'spirit' should be taken to mean 'Your rationall, immortall spirit', what he had written as 'soul' should be understood as 'your sensitive, mortal soul', and what he had written as 'body' was 'the place of residence of both, which three make up the whole man, the ò ${ }^{\prime} \chi \lambda$ npov $\dot{u} \mu \omega \mathrm{v}$ the whole of $u s^{\prime} .{ }^{54}$ So on Hammond's reading, 'soul' actually indicates the existence of a 'sensitive, mortal soul' in all human beings, while 'spirit' refers to the intellective, rational soul.

Thus, alongside the natural philosophy of Pierre Gassendi (1592-1655), Willis also refers to 'the most Learned Divine, our Dr Hammond'. John P. Wright has written the only essay that I know of that discusses Gassendi's influence on Willis's physiology, and more should be said about the influence of Gassendi on Willis and on English natural philosophy more generally. ${ }^{55}$ However, no one has yet considered the significance of Willis's reference to Hammond's paraphrase of 1 Thess: 5:23 in the De Anima Brutorum. ${ }^{56}$ It is a reference that merits some further elaboration, if only because Hammond's tripartite vision of human nature was forged not from a straightforward reading of the Bible itself, but over the course of many years of argumentation with reformed critics of the Church of England.

Much of the animus directed at the Church of England as it had existed in the 1630s arose from Laud's imposition of innovative ceremonies, his use of legal prosecution to cow non-conformists and his insistence on a strict observation of the Book of Common Prayer in worship. ${ }^{57}$ The resulting backlash went to an opposite extreme, with an attempt to impose a new liturgical standard. The parliamentary ordinance appended to the Directory, the manual intended to replace the Prayer Book, lamented how 'the many unprofitable

${ }^{53}$ Calvin, op. cit. (note 49), II.viii.1.

${ }^{54}$ Henry Hammond, A Paraphrase and Annotations Upon All the Books of the New Testament (London, 1653), 711.

55 John P. Wright, 'Locke, Willis, and the seventeenth-century Epicurean soul', in Margaret J. Osler (ed.), Atoms, Pneuma and Tranquility; Epicurean and Stoic Themes in European Thought (Cambridge: Cambridge University Press, 1991), 239-58.

56 Willis, Soul of Brutes, op. cit. (note 5), 40-1.

57 John Morrill, 'Religious Context', 46 and 52-68; John Morrill, 'Attack on the Church of England', both in The Nature of the English Revolution, op. cit. (note 19), esp. 172-3; Kenneth Fincham and Nicholas Tyacke, Altars Restored; The Changing Face of English Religious Worship, 1547-c.1700 (Oxford: Oxford University Press, 2007), 225; Spurr, Restoration Church, op. cit. (note 21), 5-7: 18-20; Bosher, Restoration Settlement, op. cit. (note 21), 16-7. 
and burdensome Ceremonies... have occasioned much mischief' and disturbed 'the Consciences of many godly Ministers and people who could not yeeld unto them'. ${ }^{58}$ The independent minister John Owen (1616-83) also used this language of conscience in his objections both to the old Stuart church and to the Restoration establishment. Owen was trusted by Cromwell, and sent by Parliament to serve as Dean of Christ Church - the same college where Willis and Hammond worked and lived - in 1651. He had earlier delivered a series of sermons in the 1640s emphasising the conscientious objections of puritanically minded reformers to Laud's church. Preaching to the Commons in 1646, Owen decried the 'Innovations of the late Hierarchists; In worship, their paintings, crossings, crucifixes, bowings, cingings, Altars'. He wondered what else they could be 'but Roman vernish, an Italian dresse for our devotion' while 'In doctrin, the Divinity of Episcopacy... freewill predestination on faith, yea works fore-seen' were all 'but help... to make all our articles of Religion speak good Roman-Catholicke'. ${ }^{59}$ Those who thought worshipping alone would suffice for their redemption 'denie the irresistibilitie, and uncontrolable power of God's will, affirming, that oftentimes he seriosuly willeth, and intendeth what he cannot accomplish'. ${ }^{60}$ Following the Restoration, Owen continued to object to the imposition of the Prayer Book. To force people to worship God against the 'Light, Dictates, or Convictions of their own Consciences' was to undermine the 'whole harmony of divine Providence in the Government of the World'. ${ }^{61}$ Owen's language invoked the will of God, and enlisted the possibility of inspiration, as forces of providential change.

Against this language of conscience, private illumination and providence, Hammond repeatedly invoked the human body to portray conscientious objections as erroneous expressions of passion. In his Of Conscience (1645), Hammond asserted that most perceptions of 'conscience' were in fact bodily impulses. What non-conformists claimed to be the workings of their conscience, impelling them to resist their magistrate and disobey the authority of the clergy, was instead any combination of humour, 'phansie', zeal, diabolical suggestion or false doctrine. ${ }^{62}$ With particular reference to humour, Hammond observed that it was always a 'matter of some difficulty to distinguish betweene my naturall and my spirituall inclinations', by which he meant 'the motion of my sensitive appetite, and my diviner principle, my lower and my upper soule'. ${ }^{63}$ Hammond also deployed this distinction between upper and lower souls in Of Sinnes of Weaknesse, Willfulnesse (1645), a precursor to the trifold theory of the human being that Hammond defended in his paraphrase of 1 Thessalonians 5:23. The conscience, properly understood, was a source of restraint, not action. For Hammond, it was when the 'conscience, or spirit, or upper soule' failed to resist the impulses of the body that many sins were committed. ${ }^{64}$

Hammond's focus on the body provided him with a means of justifying the need for strict uniformity in the worship of God. Hammond's views can plausibly be said to be in line with those of Sheldon and Willis, as these men each believed that the postures and

\footnotetext{
58 A Directory For The Publique Worship of God, Throughout the Three Kingdoms of England, Scotland, and Ireland (London, 1644), 1.

59 John Owen, A Vision of Unchangeable Free Mercy (London, 1646), 29.

60 John Owen, A Display of Arminiansime (London, 1643), 3.

61 John Owen, Truth and Innocence Vindicated in a Survey of a Discourse Concerning Ecclesiastical Polity, and the Authority of the Civil Magistrate over the Consciences of Subjects in Matters of Religion (London, 1669), 70.

62 Henry Hammond, Of Conscience (Oxford, 1645), 10, 12.

${ }^{63}$ Ibid., 9-10.

${ }^{64}$ Henry Hammond, Of Sinnes of Weakness, Willfullness: and Appendant to it, a Paraphristicall explication of two difficult Texts, Heb. 6. and Heb. 10 (Oxford, 1645), 6-8, quoted from 8.
} 
ceremonies described in the Prayer Book were essential to the true religion. Though it was used in different ways, the Book of Common Prayer contains precise instructions for the speech and posture of clergy and congregation, instructions that critics like Owen found offensive and impious. Yet a comparison of the 1638 and 1662 editions reveals a trend towards even more precision regarding the posture of the clergy and congregation. Both editions dictate a general confession to be made to the minister in morning prayer, with the congregation kneeling. The 1662 edition makes it explicitly clear that the congregation was to receive the general absolution 'still kneeling'. This revision was one of the outcomes of the Savoy Conference, and reflects an approach to Prayer Book worship that would have appealed to Willis and his circle at Christ Church. ${ }^{65}$ The posture of the congregation was one of many issues that reformers raised. Parliament intended the Directory to address the 'manifold Inconveniences that have arisen by the Book of Common Prayer in this Kingdom'. Appealing to God's providence and to the reformed churches on the continent, the Directory outlined a liturgy that was devoid of the ceremonialism in the Prayer Book. Particularly salient was the invective against kneeling. All who are to assemble in the church should enter, 'not irreverently, but in a grave and seemly manner' while 'taking their seats or places without Adoration, or Bowing themselves towards one place or another' ${ }^{66}$

By 1662 the Church of England restated the very conformity that its critics had so roundly rejected. Hammond died in 1660, but his criticisms of the Directory exhibit an earnest belief that Prayer Book ceremony moved hearts and minds through discipline and order. What Hammond found in the Directory was so formless as to be a call for the destruction of 'all Liturgy' as 'the only way of security to Gods worship'. The result would not be reformation but lawlessness and immorality, the 'turning God and Christ, and all the Articles of the Creed out of mens braines also, and not (as yet it is) only out of their hearts' ${ }^{67}$ Drawing inspiration from the Bible and from history, Hammond insisted that humans were naturally predisposed to worship God in accordance with the Prayer Book ceremony. To demonstrate the natural place of song in religion, Hammond referred to Galen - whose De Usu Partium he read as being filled with reverent appeals to divine workmanship. The Prayer Book was that natural order perfected. ${ }^{68}$ When he was writing these arguments about the nature of piety in 1646, Hammond was aware that Charles was contemplating a peace settlement that would include a change in the governance of the church. For Hammond, the abolition of episcopacy was as destructive to the institution of the true religion as the rejection of Prayer Book worship. ${ }^{69}$

Whereas Hammond had enlisted Galen, Willis endeavoured to provide a description of human nature that would disclose the connection between the mind and the body in a way that could clarify the effects and benefits of religion. Evidence for this comes not only from the dedicatory epistles of every one of his neurological works but also from the eighth chapter of the De Anima Brutorum, where we find Willis describing various 'Passions or

65 The Book of Common Prayer, And Administration of the Sacraments, And Other Rites and Ceremonies of the Church of England (London, 1662), B4v. Spurr, Restoration Church, 38-40; Bosher, Restoration Settlement, 226-30.

${ }^{66}$ Directory, op. cit. (note 58), A1r, 5.

${ }^{67}$ Henry Hammond, A View of the New Directorie and a Vindication of the Ancient Liturgie of the Church of England in Answer to the Reasons Pretended in the Ordinance and Preface, for the Abolishing the One, and Establishing the Other (London, 1646), 27.

68 Ibid., 29.

${ }^{69}$ Mortimer, Reason and Religion in the English Revolution, op. cit. (note 48), 130-1; Henry Hammond, Considerations of Present Use Concerning the Danger Resulting From the Change of Our Church Government (London, 1645), 6-7: 12-3. 
Affections' of the corporeal soul. Amongst these he lists four basic types: 'Physical, or Metaphysical, or Corporeal, or Moral'. Physical passions include bodily reactions to the perception of beauty or love. Willis describes 'corporeal' and 'moral' passions under the same heading and focuses on examples of pleasure and grief. I will describe in more detail below precisely what Willis says about how the spirits move through the brain and nerves to produce motions, sensations and memories. Here it will be sufficient to note that Willis's physiological theory, and the anatomical observations he provided to substantiate that theory, focused on the operations of an intermediate corporeal soul. This corporeal soul was present in both humans and animals, though in humans there was also a wholly distinct rational and incorporeal soul. Nevertheless, the corporeal soul served the incorporeal rational soul as the instrument of sensation, imagination and memory; accordingly, it was necessary to understand how the motions of that corporeal soul led the human mind to contemplate higher principles like God and the difference between virtue and vice.

In the midst of his description of 'metaphysical' affections, which entail the contemplation of God or higher principles of good and evil, Willis betrays his predisposition towards Prayer Book ceremony. Because 'Sacred Affections are not performed by the mere Conceptions of the Mind' but require as well the motion of the spirits through the brain, it was important to recognise that thinking about God required the proper posture. Contemplating the divine aroused such a commotion of the spirits in the brain that the heart was typically compelled to pump ever faster. This, in turn, would produce ever more spirits in the brain, in a feedback loop that could produce passions of ecstasy. ${ }^{70}$ To avoid this condition it was necessary to kneel. Since the 'whole Corporeal Soul is Commanded by the Rational Power', kneeling was a deliberate (rather than a reflexive) bodily movement. It was a choice that should be made 'in Adoring God', forcing the corporeal soul and the body to 'bow [itself] before the Deity, and as it were lye prostrate on the Ground'. This posture restrained the flow of animal spirits to the heart, which would in turn limit the flow of blood into the brain, 'lest it should... be carried towards the Brain with too impetuous a Rapture'. Such a posture allowed 'the Rational Soul' to order 'the Spirits inhabiting the Brain into sacred Conceptions and Notions'. ${ }^{71}$

Willis looked upon the structure of the brain and nerves as evidence that the human body and soul were joined such that any legitimate meditation on God and salvation required the rituals described in the Prayer Book. The posture of the congregation continued to be a divisive point of controversy, and the continued insistence that the congregation be made to bow continued to offend non-conformists after the Restoration. With the publication of the De Anima Brutorum in 1672, Willis re-emphasised what Hammond had argued in the 1640s: humans have two souls, one immortal, incorporeal and rational, the other corporeal and animalistic. Willis's neurology was intended to ground this struggle between the two souls, which had been worked out by Hammond in both polemical and exegetical publications, in a host of new anatomical facts about the brain and nerves.

\section{III}

Given the political and religious significance of Willis's dedicatory epistles to Sheldon, and his direct reference to Hammond's peculiar exegesis of the Pauline epistles, we are

\footnotetext{
${ }^{70}$ Willis, Soul of Brutes, op. cit. (note 5), 46.

${ }^{71}$ Ibid., 47.
} 
now in a position to re-evaluate the broader intellectual history of Willis's neurological project. In the first place, accepting that Willis's publications were intended to participate in a broader debate over the authority and identity of the Church of England helps to clarify the references to religious and moral principles that are scattered throughout his neurology. But the political context also exposes the strong probability that Willis approached the anatomy of the brain and nerves from 1660 committed to a preconception about the nature of the soul, and willing to innovate in the anatomical realm to defend his religion.

Perhaps unsurprisingly, Willis's own recollection of how he came to write the Cerebri Anatome is a story about a physician who abandons classical authority and embraces the direct observation of things themselves. The story Willis relates in the preface to the Cerebri Anatome begins with his tenure as Sedleian Professor of Natural Philosophy in 1660. He was required at this time to lecture on Aristotle's natural philosophy, which included the De Anima, Meteorologia and the shorter discussions that formed the Parva Naturalia. From these texts, Willis culled some arguments about the natural faculties of the soul, 'and from the appearances raised some not unlikely Hypothesis, which. . . at length accrued into a certain System of Art and frame of Doctrine'. However, Willis quickly grew sceptical of the theories he had derived from the 'received Opinions of others' and chose instead to 'believe Nature and ocular demonstrations', and he tells us that he 'betook [him]self wholly to the study of Anatomy'. ${ }^{72}$ The result would be an analysis of mental faculties based upon 'an exact Neurology or Doctrine of the Nerves' ${ }^{73}$ This is the moment where Willis determined he was better served using a scalpel than a pen 'to unlock the secret places of Mans Mind'. ${ }^{74}$ The image Willis constructs is one of a turning away from books and towards a consideration of things as the source of truth.

Adding further to this image of Willis as an adherent of the new learning is his humble acknowledgement that the first works of neurology were really the product of many eyes and many hands. Willis acknowledged the assistance of Richard Lower (163191), Thomas Millington (1628-1704) and Christopher Wren (1632-1723) - the Savilian professor of astronomy who drafted illustrations for both the Cerebri Anatome and the De Anima Brutorum. ${ }^{75}$ Alongside these men, Willis became 'addicted... to the opening of Heads especially, and of every kind, and to inspect as much as I was able frequently and seriously the Contents', even to the extent that 'no day almost past over without some Anatomical administration; so that in a short space there was nothing of the Brain, and its Appendix within the skull, that seemed not plainly detected, and intimately beheld by us'. ${ }^{76}$ All of this casts Willis alongside other major early modern 'scientists' as a man dedicated to factual precision and to argument from experience, rather than from textual authority.

However, it seems on closer inspection that Willis already had in mind what he would say about the functions of the brain and nerves well before he wrote the Cerebri Anatome. In a letter sent to Boyle on 18 January 1662, Lower (Willis's most instrumental assistant) summarised the progress the group had made and described what Willis had showed him 'according to his opinion of the use of the cerebellum for involuntary motion', and he

\footnotetext{
72 Willis, Anatomy of the Brain, op. cit. (note 5), 45.

73 Ibid., 106.

74 Ibid., G2r.

75 Allister Neher, 'Christopher Wren, Thomas Willis and the Depiction of the Brain and Nerves', Journal of Medical Humanities, 30, 3 (2009), 191-200.

${ }^{76}$ Willis, Anatomy of the Brain, op. cit. (note 5), G4v.
} 
informed Boyle that 'finding most parts of the brain imperfectly described, [Willis] intends to make a whole new draught thereof, with the several uses of the distinct parts, according to his own fancy, seeing few authors speak any thing considerable of it' ${ }^{77}$ Lower's account of Willis's role in the research that led to the Cerebri Anatome indicates that the first neurology was not the product of negotiated collaboration, nor was it the outcome of a series of disinterested anatomical observations; rather, it represented Willis's own opinions (his 'fancy') about how the brain and nerves worked. ${ }^{78}$ There is certainly no mistaking the originality of Willis's accomplishments. Anthony Wood recognised that Willis's fame owed less to his personal demeanour than to his ingenuity as a physician, for he was 'a plain man, a man of no carriage' who nevertheless laid 'a lasting foundation of a body of Physick chiefly on Hypotheses of his own framing' ${ }^{79}$

Willis's story about his dissatisfaction with Aristotle and established doctrines governing the soul is not wholly misleading, since the De Anima and its related texts had raised questions about the faculties of the soul and its relationship to the body that commentators had for centuries (and without success) sought to clarify. However, it is worth taking Lower's evaluation of Willis's process seriously as well. Dissecting brains and nerves in the middle of the seventeenth century was no easy task - Willis's gratitude to Lower's skills as a surgeon was quite genuine. And it is still unclear how Christopher Wren managed to produce the remarkably detailed images of the brain that adorn the Cerebri Anatome and the later De Anima Brutorum, given the fact that other anatomists freely admitted the brain was the most fragile and most difficult organ to dissect. ${ }^{80}$ We should therefore regard Willis's depiction of his own project as the product of rote anatomical investigation, as arising purely from a consideration of things themselves, with raised eyebrows. Lower's observation to Boyle that Willis had always intended to describe certain functions of the brain in accordance with his own fancy is probably the most accurate description of Willis's intellectual process we have. It serves as a reminder that the image of Willis 'discovering' truths from the brain is a carefully manicured one that he deployed in order to compel the assent of a highly educated readership.

Lower's letter is also important because it hints at the fact that Willis was fully aware that no anatomist had yet aspired to such an extensive anatomy of the brain. The neurologist therefore found himself with ample opportunity both to upstage his anatomical predecessors and to defend his own orthodox conception of the soul by means of a totally new anatomy of the brain and nerves. The political necessities of the Restoration therefore help us to better understand Willis's defiance of what was an established disciplinary distinction between anatomy (or the purely observational study of the body and its structure) and physiology (or the broader consideration of human nature and natural philosophy). The remainder of this section is devoted to examining the content of Willis's neurology in light of what was known about the brain, in order to evaluate his contribution to the anatomical learning of his time.

Throughout his career, Willis praised the utility of 'anatomy' and the power of experiment and observation. He used this term before 1660 to refer to the chemical

\footnotetext{
${ }^{77}$ Michael Hunter, Antonio Clericuzio and L.M. Principe (eds), The Correspondence of Robert Boyle (London: Pickering and Chatto, 2001), ii. 1-3, emphasis mine.

78 Cf. Frank, 'Willis and His Circle', op. cit. (note 31), 118-29.

79 Wood, Athena, op. cit. (note 1), ii. 402-3.

${ }^{80}$ For a cutting critique of Willis's neurological theories, see for example Ysbrand van Diemerbroeck, The Anatomy of Human Bodies, Comprehending the most Modern Discoveries and Curiosities in that Art, William Salmon (trans.) (London, 1689), esp. 404. See also the discussion of Nicolas Steno below.
} 
separation of substances into their elementary principles; after 1660, he used this term in its familiar sense, to refer to the dissection of human and animal bodies. He was an autodidact dedicated to experiment rather than purely bookish speculation, an orientation shared by other influential proponents of the new learning at Oxford in the 1640s and 1650s. As I mentioned above, the culmination of his experience at Oxford were the De Fermentatione, the De Febribus and the De Urinis. These works proceeded from Willis's own chemical 'anatomy' of substances into their principle parts of spirit, sulphur, salt, water and earth. The first chapter of his De Febribus is titled 'The Anatomy of the Blood: and its Resolution into Five Principles; the Comparing it with Wine and Milk'. Here, Willis sought to contribute to 'the thorough instauration of Physick' on a foundation 'which our most Famous Harvy hath laid, the Circulation of the Blood'. Willis hoped to follow Harvey in emphasising the power of anatomical research to disclose new truths about the body. ${ }^{81}$ From Harvey, Willis not only learned about the circulation of the blood, but also about the power of observable facts in defending natural principles.

The Cerebri Anatome was accordingly intended to provide a factual basis for all of Willis's subsequent neurological publications, and it is worth summarising that work here. The Cerebri Anatome is divided into twenty-nine chapters: the first twenty chapters concern the contents of the head, while the final nine chapters are devoted to the nerves. Chapter one details Willis's method of dissection, with subsequent chapters providing descriptions of particular parts of the brain and nerves and their functions. His instructions are precise. Having separated the skull, the anatomist was then carefully to remove the top half of the harder membrane (the dura mater) and reveal the top of the brain. He was to lift the brain out of the lower part of the skull, taking note of the arteries and veins running to and from it, and observe how they penetrated the outer membrane and inner, softer membrane (the pia mater) - and how they were distributed in the marrow of the organ. Having severed the ten pairs of nerves running to the base of the brain, the anatomist was then to place the organ on its back and to unfurl it, a procedure that would reveal the slender connections between the three principal parts of the brain: the cerebrum, medulla oblongata and cerebellum, and the distinctive corpora striata (or 'streaked bodies'). This procedure also revealed the two cerebral ventricles, those underneath the foremost part of the cerebrum. Willis categorised the nerves emerging from the cerebrum into twelve pairs and ascribed specific functions to each pair. ${ }^{82}$

Willis not only provided a novel classification for the internal structures of the brain, he also claimed that the structures he observed were the neural loci responsible for certain bodily and mental functions. He was the first anatomist to make a distinction in function between the cerebrum and cerebellum: the former, the larger forebrain, was responsible for higher faculties such as memory, sensation and imagination, and in human beings the cerebrum also housed the rational soul. The smaller hindbrain, or cerebellum, maintained the involuntary functions in humans and animals. Willis's analysis involved the comparison of animal brains to those of humans; he did so primarily because 'humane Heads... are not so readily to be had', but also because the similarities and differences between species were not only instructive to anatomists and natural philosophers, but provided evidence for the existence and operations of the immortal human soul. ${ }^{83}$ This process of comparison was one way in which Willis concluded that the cerebellum was

${ }^{81}$ Willis, Of Fevers, op. cit. (note 5), 47, 45.

82 Willis, Anatomy of the Brain, op. cit. (note 5), c.1 passim.

83 Ibid., 46. 
responsible for involuntary functions, while the cerebrum was the physical locus of the immortal soul - while all animals had cerebella, only humans had large cerebra. Willis also described with great specificity the functions of different parts of the cerebrum. The imagination he attributed to the corpus callosum, sensation to the corpora striata, and memory to the ashy exterior of the cerebrum. ${ }^{84}$

Willis's contemporaries shared a set of assumptions about the nervous system. They believed the nerves to be a network of diminutive tubes, filled with a substance commonly referred to as the 'animal spirits'. The nature of the nerves and their role as conduits for the animal spirits was generally accepted from the authority of Galen, and these were the terms that Willis also used in his neurological works. ${ }^{85}$ However, though Willis used language that had been rehearsed by anatomists for centuries, he made some radically different assertions regarding the operations of these corporeal 'spirits'. In the first place, Willis was not merely parroting a textual commonplace. In the second edition of his De Fermentatione (1660), which contained additional material not found in the 1659 edition, Willis sought to establish the existence of spirits experimentally by using an alembic, a device used by chemists to perform distillations. ${ }^{86} \mathrm{He}$ also used a microscope to investigate the structure of nerves, especially as they proceeded into muscular tissue, in order to ascertain how they moved the body. ${ }^{87}$ Like many of his contemporaries, Willis held that the animal spirits were the material cause of many of the processes responsible for life, and that they were derived in some way from the vital spirits found in the blood.

Particularly remarkable was the way in which, in the midst of his anatomical observations, Willis elaborated upon how animal spirits travelled through the brain during acts of imagination, sensation and memory. He pushed beyond the basic assumption that these spirits played a role in animal physiology that was both essential and highly generalised. For example, if a woman perceives a rose, the light reflected from the rose strikes nerves in her eye and causes a particular movement of the animal spirits in those nerves to travel to the brain. Motions of this kind through the corpora striata cause in turn 'a perception or inward sense of the Sensation outwardly had or received'. After this initial act of sensation, if the motion is strong enough, it is conveyed 'through the [corpus callosum]' which causes an act of 'Imagination'. If 'the same fluctuation of Spirits is struck against the cortex of the Brain', towards 'its utmost banks, it impresses on it the image or character of the sensible Object, which, when it is afterwards reflected or bent back, raises up the memory of the same thing, ${ }^{88}$

Perceptions could often spark different memories because the animal spirits causing the perception might follow a neural pathway previous perceptions had used. The formulation of memory occurred only after an act of imagination, due entirely to the fact that the spirits had to flow from the interior of the brain through the corpus callosum (the seat of the imagination) to the boundaries of the cerebrum (the seat of the memory). Likewise, recalling anything from memory required an act of the imagination. This occurred when the spirits flowed from the outer perimeter of the brain back into the central corpus

\footnotetext{
84 Willis, Anatomy of the Brain, op. cit. (note 5), 57, 78-9.

${ }^{85}$ Cf. Rose, The History of British Neurology, op. cit. (note 2), 35.

86 Willis, Of Fermentation, op. cit. (note 5), 3. Pordage's translation is taken from the enlarged edition, which appeared in 1660 and contains a number of alterations from the earlier 1659 text. See Thomas Willis, Diatribae Duae Medico-philosophicae...Editio Secunda, Ab Authore recognita, atque ab eodem multiplici Auctario locupletata (London, 1660), 6.

${ }^{87}$ Willis, Anatomy of the Brain, op. cit. (note 5), 73.

${ }^{88}$ Ibid., 79.
} 
callosum. The spirits were therefore in a constant, tonic motion. They moved from the body into the brain, where they activated various psychological faculties. Conversely, when the spirits flowed from the brain to the body, they caused voluntary and involuntary motions. ${ }^{89}$

Anatomy was, for Willis, the necessary foundation for speculations about the human soul, its normal physiology and its pathological states. It was through the anatomy of the brain and nerves that Willis sought to lay 'a firm and stable Basis... on which not only a more certain Physiologie than I had gained in the Schools, but what I had long thought upon, the Pathologie of the Brain and nervous stock, might be built' ${ }^{90}$ The order of his publications exemplifies his approach: the Cerebri Anatome laid the anatomical foundation for Willis's subsequent works on pathology (the Pathologiae Cerebri and the second part of the De Anima Brutorum) and physiology (the first part of the De Anima Brutorum). In all of these works, Willis sought to demonstrate that the anatomist could reveal how the body influenced the mind, and how the mind moved the body. Willis therefore attempted to connect what was described in the Cerebri Anatome to broader arguments about the relationship between the soul and body (the subject of the De Anima Brutorum).

Such an approach to philosophy through anatomy was highly original. Prior to Willis, anatomists were willing to admit that animal spirits were necessary for the various lower processes of digestion and movement, but they grew anxious when it came time to describe the brain and its function. A cursory description of the brain and its basic functions in maintaining life had proven sufficient. Few authors are cited by name in the Cerebri Anatome, though the text is rich with allusions. For example, Willis dismissed anatomists who had 'cut [the cerebrum] as it were into slices or parts', only then to wrongly describe the 'Phaenomena arising by chance from such a dissection' as 'true parts of the Brain'. ${ }^{91}$ The cross-sectioning of the brain from the top down was devised to demonstrate Galen's explanation of the ventricles and their use in producing pneuma or the spiritus animales. According to Galen, this substance was derived in part from vital spirits gathered in the brain from the blood, which were then mixed with air that had been drawn into the brain from the nose. ${ }^{92}$

The need to critically understand Galen's claims by reference to the body itself is nowhere better epitomised than in Andreas Vesalius's iconic De Humani Corporis Fabrica Libri Septem ([Seven Books on the Construction of the Human Body] 1543). It has long been argued that the publication of the Fabrica marked the beginning of an intensified, and international, interest in learning anatomy by dissection. However the image of Vesalius as a radical, modernising influence has its genesis with encyclopedists of the eighteenth century, and it has obscured the degree to which Vesalius was merely emphasising the commonplace assertion that observation and dissection were critical aspects of anatomical learning. ${ }^{93}$ Indeed, though Vesalius was elsewhere critical of Galen,

${ }^{89}$ Willis, Anatomy of the Brain, op. cit. (note 5), 91.

90 Ibid., G3r.

91 Ibid., 45, 49

92 Galen, On the Usefulness of the Parts of the Body, Margaret Tallmadge May (trans.) (New York: Cornell University Press, 1968), i. 53-5: 61-3.

93 Ephraim Chambers, Cyclopaedia: Or, an Universal Dictionary of Arts and Sciences (London, 1741), s.v. 'Anatomy'; Andrea Carlino, Books of the Body; Anatomical Ritual and Renaissance Learning, John Tedeschi and Anne C. Tedeschi (trans.) (Chicago: Chicago University Press, 1999), 27-53: 40-1; Andrew Wear, 'Medicine in Early Modern Europe, 1500-1700' in Lawrence I. Conrad, Michael Neve, Vivian Nutton et al. (eds), The Western Medical Tradition 800 BC to AD 1800 (Cambridge: Cambridge University Press, 1995), 273-85; 
his description of the brain and its functions virtually echoes Galen's De Usu Partium. Vesalius's procedure for dissecting the brain focused on the ventricles and the corpus callosum as the most distinctive parts of that organ. Whereas Willis's method was designed to facilitate subsequent philosophical speculations about the soul, Vesalius was perhaps more concerned that the cutting of the brain should exhibit the skill of the dissector. The exhibition of these parts required the removal of the top of the brain with a sharp razor, such that 'if more cuts are repeated the operation is disgracefully botched'. ${ }^{94}$

In directing the anatomist to disregard the ventricles, and to instead consider the brain as a whole, Willis followed the pioneering work of Costanzo Varolio (1543-78). In sharp contrast to Willis, however, Varolio took up his knife in order to refute all who philosophised about the soul by reference to the anatomical substance of the brain. In his Anatomiae, Sive de resolvtione Corporis Humani ([Of Anatomy, or Concerning the Resolution of the Human Body] 1591), Varolio described the same basic method Willis employed decades later in the first work of neurology. He gave detailed instructions on how to excavate the brain without cutting it into sections. Even Varolio's method was not totally original; he referred his reader to the fourth book of Vesalius's Fabrica as an example of what the brain ought to look like in this position. ${ }^{95}$ Once the brain was taken wholly out of the skull, it became clear to Varolio that these ventricles were accidental spaces within the windings of cerebrum, rather than structures that served to produce the animal spirits. ${ }^{96}$ Varolio went further and asserted that the ventricles were not the loci in which animal spirits were produced, but were instead 'two conspicuous cavities... in which such excrement is deposited, so much as in a sewer' ${ }^{97}$ Like Varolio, Willis proposed 'that [the cerebral] Ventricles are not formed out of the primary intention of Nature, but result only secondarily and accidentally from the complication of the Brain', adding that 'almost all Anatomists, who are of a later Age, have attributed that vile office of a Jakes or sink to this more inward chamber of the Brain'. ${ }^{98}$

Like so much of his writing, Willis only alluded to major trends in anatomy and natural philosophy. He had no wish to engage in the display of learning so common to other learned physicians and anatomists, whose manuals catalogued in rebarbative detail the approaches of their predecessors. In this regard, Willis's manual is quite different from that of Johann Vesling (1598-1653), whose manual was used by students in Interregnum Oxford, and who discussed the brain as it would have appeared after being cross-sectioned in the traditional style. ${ }^{99}$ In his De Humani Corporis Libri Decem ([Ten Books Concerning the Human Body] 1627), Adriaan van den Spiegel did not propose his own method of dissection until he had treated both the cross-sectional and Varolian methods. Van den Spiegel agreed with Varolio that the cerebral ventricles served to remove waste, and that what had been supposed to be the third and fourth ventricles were merely accidental spaces

\footnotetext{
Andrew Cunningham, The Anatomical Renaissance; The Resurrection of the Anatomical Projects of the Ancients (Aldershot: Scolar, 1997), 88-142.

94 Andreas Vesalius, De Humani Corporis Fabrica Libri Septem (Brussels, 1543), 652, ‘...plurbius enim reiteratis sectionibus, operatio turpiter uitiatur'.

95 Costanzo Varolio, Anatomiae, Sive De resolvtione Corporis Humani Ad Caesarem Mediouillanum Libri IIII (Frankfurt, 1591), 141.

96 Varolio, Anatomiae, 132.

97 Ibid., 8-9.

98 Willis, Anatomy of the Brain, op. cit. (note 5), 79.

${ }^{99}$ Frank, Oxford Physiologists, op. cit. (note 8), 50; Johann Vesling, The Anatomy of the Body of Man, Nicholas Culpepper (trans.) (London, 1653), 58-64; This is Culpeper's translation of Johann Vesling, Syntagma Anatomicum: Locis Plurimis Auctum, Emendatum, Novisque Iconibus Diligenter Exornatum (Padua, 1647).
} 
between the various parts of the brain. ${ }^{100}$ In his Corporis Humani Disquisitio Anatomica ([An Anatomical Investigation of the Human Body] 1651), Nathaniel Highmore (161385) referred to the way Vesalius, Varolio and van den Spiegel had described the brain: these men were the best of the Republica Anatomica. Though he agreed with Varolio's conclusions about the ventricles and thought his anatomical procedure superior, he still described how one could dissect the brain in order to provide a gloss on Galen. ${ }^{101}$

Rather than refer to the works of Galen or even to more recent authors, Willis was probably confident his readers would have recognised the influence of Varolio and his rejection of the cross-sectional method epitomised in Vesalius's Fabrica. Willis's readers would also have recognised how his description of parts and their use - the corpora striata (for sensations), the corpus callosum (for imagination) and the ashy exterior of the cerebrum (for memory) - had no precedent in either classical or contemporary sources.

Willis's use of anatomy played upon a disciplinary division between anatomy and natural philosophy. Though the precise nature of this division was frequently a matter of a broader dispute about the relationship between natural philosophy and medicine, Andrew Cunningham has reminded us that the 'old anatomy' was concerned merely with the dissection and description of the body. Speculations about the soul, its faculties and its place in nature were the purview of 'old physiology'. ${ }^{102}$ At first glance, it appears Willis's neurology followed this basic framework. He published his Cerebri Anatome in order to establish facts from the dissection of the brain and nerves that he could use in his subsequent publications about the pathology and physiology of the soul. However, in pursuing his own anatomical investigation, Willis proposed that anatomy was the essential foundation of physiology. By 'anatomy', Willis did not mean the synthesis of anatomical works from either classical antiquity or contemporary authors, but rather the actual physical inspection of the brain and nerves. ${ }^{103}$

Though Willis was the first to insist that physiology refer to a direct inspection of the brain, he was not the first to propose that the functions of the soul were localised in the brain itself - late fifteenth-century natural philosophers had long argued that the faculties of the soul were located in the ventricles of the brain. However, and in ways that reflect the tensions between the 'old anatomy' and 'old physiology' noted by Cunningham, anatomists before Willis were roundly critical of explanations of the soul that localised psychological faculties to parts of the brain. Following the production of definitive Greek editions of Galen in 1525, and the systematic attempt at Padua and Bologna to interpret Galen's text through dissection, anatomists rejected earlier claims that the soul's faculties were located in the cerebral ventricles. Gregor Reisch's epitome of natural philosophy, the

\footnotetext{
100 Adriaan van den Spiegel, De Humani Corporis Fabrica Libri Decem (Venice, 1627), 316: 325.

${ }^{101}$ Nathaniel Highmore, Corporis Humani Disquisitio Anatomica in qva Sanguinis Circulationem in quavis Corporis particular plurimis typis novis, ac Ænygmatum Medicorum succincta dilucidatione ornatam prosequutus est (The Hague, 1651), A2v, 210.

102 An overview of the relationship between learned medicine and natural philosophy is Ian Maclean, Logic, Signs and Nature in the Renaissance: The Case of Learned Medicine (Cambridge: Cambridge University Press, 2002), 80-3, and in Andrew Cunningham, 'The Pen and the Sword: Recovering the Disciplinary Identity of Physiology and Anatomy Before 1800 I: Old Physiology - the Pen', Studies in the History and Philosophy of Biological and the Biomedical Sciences, 33 (2002), 631-65; Andrew Cunningham, 'The Pen and the Sword: Recovering the Disciplinary Identity of Physiology and Anatomy before 1800 II: Old Anatomy - the sword', Studies in the History and Philosophy of Biological and the Biomedical Sciences, 34 (2003), 51-76, esp. 64-5.

${ }^{103}$ In this respect, Willis stands apart from late scholastic thinkers. See Michael Edwards, 'Body, soul and anatomy in late Aristotelian psychology', in Gideon Manning (ed.), Matter and Form in Early Modern Science and Philosophy (Leiden: Brill, 2012), 33-76.
} 
Margarita Philosophica (1503), presented one version of this controversial physiology. He explained that the brain had three primary ventricles, each of which were separated by a small membrane or skin. He located the sensus communis and the imagination in the first ventricle. The middle ventricle housed the faculties of estimation and fantasy; the last ventricle housed the faculty of memory. ${ }^{104}$

Anatomists in the mid and late sixteenth-century attacked both the anatomical and philosophical merits of this older physiology. Vesalius in particular singled out Reisch's textbook as being not merely inaccurate, but also impious. ${ }^{105}$ When Varolio set out to establish a new way of dissecting the brain, he did so to oppose the description of the ventricles represented in Reisch's textbook, and any doctrine that established the soul's dependence on the body. ${ }^{106}$ Anatomists in the early seventeenth century struck a less polemical tone, but, like their predecessors, they typically avoided any specific claims about brain function. For example, in his Historia Anatomica Humani Corporis ([Anatomical History of the Human Body] 1600), André Du Laurens rejected not only the three-ventricle physiology of the Margerita, but denied more generally the possibility that the soul depended on certain parts of the brain. When it came to describing how the animal spirits produced their effects, Du Laurens sided with Galen, who had claimed that the soul's faculties were all located in the brain and that the brain and animal spirits were instruments of the soul. ${ }^{107}$ I would suggest that this hesitance to make definitive claims about the brain was not merely deference to Galen, but reflected as well a reticence on the part of anatomists to proceed from a manual dissection of the brain to speculations about its relationship to the soul. That reticence owed much to a recognition that anatomy was merely about the description of the body and its parts, and much as well to the technical limits anatomists faced when they dissected the brain and nerves. One of Willis's earliest critics, the anatomist and naturalist Nicolaus Steno (1638-86), asserted that it was impossible to make reliable claims about the parts of the brain or their functions since the organ was so complicated and fragile. ${ }^{108}$

Willis was not ignorant of the technical difficulties he faced, but he was keenly aware that he had an opportunity to totally reform cerebral anatomy. Every anatomist before him had dissected the brain with less precision and with no intention of providing any speculation as to the function of its parts with reference to the soul. Willis was therefore free to forge boldly ahead, and to demonstrate how philosophical statements about the mind must be made with reference to anatomical facts about the brain and nerves.

\section{IV}

Willis's neurology was a monumental intervention in the world of anatomical learning, but it was not the work of a physician interested only in anatomical discovery. Instead,

\footnotetext{
104 Gregor Reisch, Natural Philosophy Epitomised: A Translation of books 8-11 of Gregor Reisch's Philosophical Pearl (1503), Andrew Cunningham and Sachiko Kusukawa (ed. and trans.) (Surrey: Farnham, 2010), 205.

105 Andreas Vesalius, On the Fabric of the Human Body; a Translation of De Humani Corporis Fabrica Libri Spetem, William Frank Richardson and John Burd Carman (trans. and ed.) (San Francisco: Norman Pub., 19982009), v. 165.

106 Varolio, Anatomiae, op. cit. (note 95), 4.

107 André Du Laurens, Historia Anatomica Humani Corporis Singularum eius Partium Multis Controuersiis \& Obseruationibus Nouis Illustrata (Paris, 1600), 534.

108 Nicolaus Steno, A Dissertation on the Anatomy of the Brain: Read in the Assembly Held in M. Thevenot's House in the Year 1665, G. Douglas (trans.) (Copenhagen: Busck, 1950 [1669]), 9, 49.
} 
the first works of neurology present a systematic defence of a specific theological conception of human nature. Willis's view of the brain and nerves was directly shaped by the orthodoxy of Sheldon's Church of England. He published his observations in order to justify the efficacy of Prayer Book liturgy on anatomical and physiological grounds. It is worth emphasising that, in aligning himself with Sheldon, Willis made sure his project stood apart from the worldly preoccupations of other physicians. As Mordechai Feingold has reminded us, there is a real danger in forgetting that theologians differed in their profession and perspective from those who devoted themselves to natural philosophy and medicine. ${ }^{109}$ Indeed, many natural philosophers wrote about religion from a perspective far removed from that of their theologically trained contemporaries. The physician and essayist Sir Thomas Browne began his Religio Medici by apologising 'for severall circumstances that might perswade the world' of his irreligion, a perception brought on by 'the generall scandall of my profession, the natural course of my studies the indifferency of my behaviour, and discourse in matters of Religion' ${ }^{110}$ Likewise in The Excellency of Theology, Compar'd with Natural Philosophy (1674), Robert Boyle asserted that exhortations to virtue were more compelling when made by 'secular' writers who endeavoured to better understand worldly pleasure. ${ }^{111}$ One of the distinctive features of the mature John Locke, also a physician by training, who in his younger years had attended Willis's lectures and owned multiple editions of his books, was his professed indifference in matters pertaining to doctrine and orthodoxy. ${ }^{112}$

Whereas it was expected physicians and natural philosophers should leave theology to the theologians, Willis had clearly designed his neurology to defend an orthodox vision of the soul and a particular conception of human nature that privileged certain religious rituals. It is not a coincidence that Willis's anatomical investigation revealed the physiological benefits of religious practices like bowing; a wholly rational exercise whose benefits were made possible by the orderliness of the nerves and brain. This was the essence of Willis's stated intention that his neurology should make 'the Wars and Strivings between our two Appetites, or between the Flesh and Spirit, both Morally and Theologically inculcated to us, [to be] also Physically understood' ${ }^{113}$

By way of conclusion, I want to offer two examples of how Willis's anatomy undermined philosophical considerations of the mind and its relationship to the body that emphasised introspection, rather than a reliance on outward acts of conformity or piety. From the perspective of Willis and his fellow Prayer Book loyalists, there were analogues to Calvinism that privileged recourse to the conscience or other forms of introspection as a sufficient and necessary source of moral information. These views of human physiology implicitly called into question the need for or efficacy of external forms of worship.

The most notable of these is the famous description of the brain made by René Descartes. Willis might have learned of Descartes's views from the Discours de la Méthode (Discourse on Method, 1637) or from Les Passions de l'âme ([The Passions of the Soul],

\footnotetext{
${ }^{109}$ Mordechai Feingold, 'Science as a Calling? The Early Modern Dillemma' Science in Context 15, 1 (2002), 79-119, he describes Willis's case on 105.

${ }^{110}$ Sir Thomas Browne, Religio Medici (London, 1642), 1, though as noted by R.H. Robbins in his entry in the $O D N B$, many of Browne's positions in the unauthorised 1642 edition were amended to be less controversial in the 1643 edition.

111 Robert Boyle, The Excellency of Theology, Compar'd with Natural Philosophy (London, 1674), sigs. A6 r-v.

112 John Locke, Some Thoughts Concerning Education: and Of the Conduct of the Understanding, Ruth W. Grant and Nathan Tarcov (eds) (Indiannapolis: Hackett Pub. Co., 1996), 199, § 34.

113 Willis, Soul of Brutes, op. cit. (note 5), A4r.
} 
1649). In both works, Descartes echoed the theory he had developed in his earlier Traité de l'Homme ([Treatise on Man]): that the 'pineal gland' in the brain was the locus of the soul. He claimed that this gland extended into the space formed by the conjunction of the cerebral ventricles, and that these cerebral ventricles and the whole nervous system were filled with animal spirits. He supposed that these spirits were separated from the blood through tiny holes that extended through the pineal gland. ${ }^{114}$ Within the human body (which Descartes famously compared to a complicated machine) these spirits produced sensations in the soul and motions in the limbs and organs by flowing through the nerves, as fluids might flow pneumatically through pipes to move an automaton. ${ }^{115}$

Descartes's role in the production and reception of Willis's neurology has not received the attention it deserves, nor has Willis's role in the transformation of Descartes's dualism. What is remarkable for my purposes is the fact that Descartes is one of few authors Willis criticises by name. In the Cerebri Anatome, he wrote that what the Famous Cartes supposes to be Nerves belonging to the pineal Glandula' were in fact only a structural feature of the brain that permitted the 'the Optick Nerves' to proceed from the spinal medullary into the corpora striata. ${ }^{116}$ Willis's alternative to Descartes's description swayed even those who found Cartesian natural philosophy appealing for their own ends. For example, Nicolas Malebranche (1638-1715) recognised (though with reservations) that Willis's description of the brain was a preferable alternative to Descartes's. ${ }^{117}$ For all his doubts about Willis's speculations, Nicolas Steno agreed that the Cerebri Anatome had presented the most precise description of the brain then available and had demonstrated that Descartes's description of the pineal gland was erroneous. ${ }^{118}$

Willis had used anatomy as a means to undermine Cartesian physiology, and some of his readers would use his observations against rival intellectuals who published accounts of the mind/body relationship that privileged innate knowledge or internal methods of spiritual edification that did not require public worship of any kind. For example, Samuel Parker (1640-88) was a theologian who referred to Willis's works in his polemical writing. By 1667, when Willis published his Pathologiae, Parker was serving as Sheldon's chaplain. ${ }^{19}$ He had already read and employed Willis's Cerebri Anatome as part of his proof of the existence of God in the Tentamina Physico-Theologica de Deo: sive Theologica Scholastica ad Normam Novae \& Reformatae Philosophiae Concinnata ([Essays on God, or Scholastic Theology Adjusted to the Standard of the New and Reformed Philosophy] 1665). ${ }^{120}$ Parker's subsequent criticism of Platonic philosophy, A Free and Impartial Censure of the Platonick Philosophie being a Letter Written to his Much Honoured Friend Mr Nath. Bisbie (1667), attacked a range of heterodox opinions, though each of the views he criticised emphasised inward spiritual or intellectual enlightenment at the expense of a holistic physiological approach to the mind and body. For example, at one point in

\footnotetext{
114 René Descartes, The World and Other Writings, Stephen Gaukroger (trans.) (Cambridge: Cambridge University Press, 1998), 143-5.

115 Descartes, The World, 147-8.

116 Willis, Anatomy of the Brain, op. cit. (note 5), 52-7.

117 Nicolas Malebranche, The Search After Truth, Thomas M. Lennon and Paul J. Olscamp (trans.) (Cambridge: Cambridge University Press, 1997), 89.

118 Steno, Anatomy of the Brain, op. cit. (note 108), 12-5, 17.

119 Jon Parkin, 'Parker, Samuel (1640-88)', ODNB.

${ }^{120}$ Samuel Parker, Tentamina Physico-Theologica de Deo: sive Theologica Scholastica ad Normam Novae \& Reformatae Philosophiae Concinnata (London, 1665), 79-98, particularly 83-4. The best discussion of Parker's Physico-Theologica is Dmitri Levitin, 'Rethinking English Phyisco-theology: Samuel Parker's Tentamina de Deo (1665)', Early Science and Medicine, 19 (2014), 28-75.
} 
his Censure, Parker proceeded from a criticism of Platonic philosophy directly into an indictment of Calvinism. ${ }^{121}$

Parker's primary target was the Cambridge Platonist Henry More (1614-87). More saw natural philosophy as a useful tool in substantiating the basic principles of Christianity. More considered himself a member of the English church, though after 1660 his theological principles, especially his liberal view of grace, and his own compliance with the Protectorate regime, led him into conflict with the newly established Restoration church. ${ }^{122}$ His own brand of Platonism had originally been fashioned in part as a response to the rise of natural philosophies that implicitly called into question the independence and even the bare existence of the immortal human soul. Especially concerning to More was the threat posed by the overtly materialistic natural philosophy of Thomas Hobbes. Equally troubling to the Cambridge Platonist was the threat of religious enthusiasm, or the claim made by individuals to direct and authoritative divine inspiration. More's ideas regarding spiritual illumination were opposed to the expectation that the body was the necessary instrument of piety. For More, the difference between divine illumination which could be obtained through the use of right reason - and bald enthusiasm could be understood by reference to the body's deceptive influences on the mind. The enthusiast was deceived by their baser animal impulses. 'Real' illumination had nothing to do with any physical process in the body, but arose from suggestions of the Holy Spirit, and then only those that were beneficial to the true church. ${ }^{123}$ Yet More was never able to demonstrate to his opponents how one could distinguish between enthusiasm and legitimate spiritual inspiration. ${ }^{124}$

Though More intended his Platonism to undermine Calvinist theology, his own insistence on a real, private illumination presented a challenge to Prayer Book loyalists like Parker. Against More's own brand of Platonic introspection, which involved a stark dichotomy between the intellectual and material, Parker proposed instead that God had fashioned the human body to be perfected through religion. Unlike the Platonists, who asserted the independent existence of moral principles whose validity did not derive from God's will but whose truths God nevertheless adhered to as well, Parker emphasised the respect to which virtues and vices were embedded wholly in bodily practice. In this regard, God had built into humans a natural means of striving for virtue. As 'the nature of Vertue consists in the minds governing the Bruitish [sic] and Animal appetites and motions of the Body', God had made the motions of the body subject to the dictates of the soul through the use of the nerves. ${ }^{125}$ To prove his point that humans had been placed in the world with mediocre but sufficient means to perfect themselves, Parker elaborated upon Willis's description of the intercostal nerve. It was within the soul's power to calm the body in

\footnotetext{
${ }^{121}$ Samuel Parker, A Free and Impartial Censure of the Platonick Philosophie being a Letter Written to his Much Honoured Friend Mr Nath. Bisbie (London, 1667), 25-7; John Henry, 'A Cambridge Platonist's Materialism: Henry More and the Concept of Soul', Journal of the Warburg and Courtauld Institutes, 49 (1986), 172-95.

122 Sarah Hutton, 'Iconisms, enthusiasm and origen: Henry More reads the bible', in Ariel Hessayon and Nicholas Keene (eds), Scripture and Scholarship in Early Modern England (Aldershot: Ashgate, 2006), $192-207$. Robert Crocker, Henry More, 1614-87: A Biography of the Cambridge Platonist (Dordrecht: Kluwer Academic Publishers, 2003), 93-106.

${ }^{123}$ Henry More, Enthusiasmus Triumphatus, or, A Discourse of the Nature, Causes, Kinds, and Cure, of Enthusiasme (London, 1656), 55.

${ }^{124}$ For a discussion of how More's opponent in Thomas Vaughan had exploited this tension in his writing, see Robert Crocker, 'Mysticism and enthusiasm in Henry More', in Sarah Hutton (ed.), Henry More (1614-87) Tercentenary Studies (Dordrecht: Kluwer Academic Publishers, 1990), 137-56. Crocker, Henry More, 45-61.

125 Parker, Censure, 190.
} 
the midst of anger, for example, by 'its influence upon those Nerves' which run 'from the Brain to the Heart' - specifically what Parker identified as Willis's 'Intercostal Nerve'. ${ }^{126}$

Parker's use of Willis suggests the first works of neurology were not just used as ammunition for the Restoration church after the fact, but were from the outset designed with that use in mind. And there is reason to suspect that Willis had read, and largely agreed with, Parker's refutation of More's Platonism. In the De Anima Brutorum, Willis began his discussion of his own theory that all animals possessed a corporeal soul, that heap of animal spirits in the brain and nerves, by attacking the opinion of Plato and the Manichees. 'I am not easily led to believe', wrote Willis, 'That the Soul of the Beast is an Incorporeal Substance, or Form', since what Plato had written about that subject 'hath already been refuted and clearly exploded, both by the Ancient and Modern both Philosophers and Theologists', so much 'that there remains no further dispute about it'. Nor would Willis consent to the theories of 'those Origenists, who have affirmed the Souls of all Living Creatures to be immaterial'. ${ }^{127}$ Willis makes no reference to More explicitly, but the allusion to 'Modern' philosophers and 'Theologists' who exploded the falsehoods of Plato points to the sort of polemic launched by Parker in the years before Willis published the De Anima Brutorum. If Willis's neurology was of value to his theological friends, it may also have been the case that the work of his theological allies, and not just the theological bedrock provided by Hammond, was of value to the neurologist as well.

The necessity of securing a lasting religious settlement in the Restoration not only encouraged Willis to intervene in the world of anatomical learning; necessity also provoked him to find 'facts' in the body to support a distinctive set of political ends. Indeed, Willis's description of the intercostal nerve is one of the more dubious anatomical 'facts' in the Cerebri Anatome - modern anatomists do not recognise the existence of this direct connection between the heart and the brain. ${ }^{128}$ Even before Willis's anatomical observations had set a new standard in European medicine for factual precision, Parker had already used his neurological thesis in the ongoing struggle to define the nature of the soul and its proper relationship to the body.

Any attempt to fit Willis's publications into a grand narrative about how neuroscience emerged organically from out of all of human experience is therefore no longer possible. Such a narrative not only disregards the important details about what Willis thought he was doing in writing the first works of neurology, it also overlooks the very essence of Willis's ingenuity and innovation. His aim was not merely to produce a straightforwardly 'scientific' theory of the brain and nerves. Instead, Willis turned to anatomy in order to defend the Restoration church and to provide his allies with evidence from which they might more effectively defend their shared conviction that we were all embodied, impassioned and fallible human beings. To Willis and his clerical circle, it was our fallibility that made the Restoration church, with all of its coercive legal authority, the necessary instrument of an order that was both politically and spiritually beneficial. In this regard, Willis's immediate political context helps us to better understand his innovation vis-à-vis the state of the art in the seventeenth century. His anatomical predecessors were actively opposed to the kind of research Willis so boldly published in the 1660s. They explicitly refused to engage in the kind of speculations that Willis aimed to substantiate in his neurology. And Willis's innovation, which is so startling

${ }^{126}$ Parker, Censure, op. cit. (note 121), 194-5.

${ }^{127}$ Willis, Soul of Brutes, op. cit. (note 5), 4.

${ }^{128}$ Knoeff points out the uniqueness of Willis's description of this nerve in op. cit. (note 34), 415. 
in light of his predecessors, makes that much more sense given the political necessities of the 1660 s.

If Willis's case is at all indicative, then modern neuroscience can no longer be regarded as the outcome of a gradual accumulation of information about neural disorders or cerebral anatomy over time. The history of neuroscience should instead be approached as a history of intellectuals who engaged in a highly specialised kind of investigation, who sought increasingly to bring anatomical observations to bear on philosophical debates about human nature. In this regard, the history of neuroscience is an important and vital part of the broader intellectual history of medicine in Europe more generally. It is the story of how speculations about the brain came increasingly to be the province of anatomists, rather than natural philosophers. It is also a history that begins in earnest with Willis, since he was the first to argue publicly for the possibility that research into the anatomy of the brain was the necessary foundation for philosophical speculations about the mind. If the problems addressed by anatomists after Willis might therefore be regarded as moves within an emerging context of literature about the brain and nerves, the particular reasons these anatomists took up their knives, and then their pens, also merits consideration. 